\title{
APLIKASI SISTEM PAKAR UNTUK DIAGNOSIS JENIS PENYAKIT PADA IKAN CUPANG DI GUBUK CUPANG HIAS
}

\author{
Muhammad Pujo Santoso', Rayung Wulan ${ }^{2}$, Siti Ayu Kemala ${ }^{3}$ \\ ${ }^{1,2,3}$ Program Studi Teknik Informatika, Fakultas Teknik dan Ilmu Komputer , \\ Univeristas Indraprasta PGRI \\ Jalan Raya Tengah No 80, Kelurahan Gedong, Pasar Rebo, Jakarta Timur \\ Pujoe.satriani@gmail.com ${ }^{1}$, utha2578@gmail.com ${ }^{2}, \underline{\text { sitikumala7891@ gmail.com }}$
}

\begin{abstract}
Abstrak
Kemajuan pada dunia percupangan di Indonesia semakin pesat, meskipun terbilang masih banyak yang menggangap remeh akan tetapi nilai jual pada ikan cupang cukup menyita perhatian oleh karena itu, banyak pembudidaya beralih mata pencaharian ke ikan hias tersebut. Saat ini, banyak kendala yang sering dihadapi para pembudidaya ikan hias tersebut salah satunya adalah kurangnya pemahaman akan metode dalam cara beternak dan merawat ikan cupang sehingga menimbulkan kematian secara massal yang diakibatkan oleh penyakit, serta pembudidaya kesulitan untuk mendeteksi gejala-gejala yang ditimbulkan sehingga mengakibatkan ikan cupang terkena penyakit. Penelitian ini bertujuan untuk memudahkan para peternak atau pembudidaya ikan cupang mengetahui serta memahami dalam mendiagnosa penyakit apa saja yang menyerang ikan cupang dengan mencari fakta - fakta berdasarkan gejala yang muncul. Adapun metode yang digunakan untuk mendiagnosa penyakit pada ikan cupang yaitu dengan metode forward chaining. Berdasarkan permasalahan serta tujuan diatas didapat hasil berupa aplikasi sistem pakar untuk diagnosis jenis penyakit ikan cupang.
\end{abstract}

Kata Kunci : Sistem Pakar, metode Forward Chaining, Diagnosis.

\begin{abstract}
Progress in the world of hickey in Indonesia is increasingly rapid, although there are still many who consider it trivial, the selling value of betta fish is quite attention-grabbing, therefore, many cultivators switch their livelihoods to these ornamental fish. Currently, there are many obstacles that are often faced by ornamental fish cultivators, one of which is the lack of understanding of methods in raising and caring for betta fish, causing mass deaths caused by disease, and cultivators having difficulty detecting the symptoms caused, resulting in fish betta get disease. This study aims to make it easier for betta fish farmers or cultivators to know and understand in diagnosing any diseases that attack betta fish by looking for facts based on the symptoms that appear. The method used to diagnose disease in betta fish is the forward chaining method. Based on the problems and objectives above, the results obtained in the form of an expert system application for the diagnosis of betta fish diseases.
\end{abstract}

Keyword : Expert System, Forward Chaining method, Diagnosis.

\section{PENDAHULUAN}

Kemajuan pada dunia percupangan di Indonesia seperti kita ketahui semakin berkembang pesat meskipun terbilang masih banyak yang menganggap remeh, akan tetapi nilai jual pada ikan cupang tersebut tebilang cukup menyita perhatian. Oleh karena itu, banyak masyarakat yang beralih mata pencaharian menjadi pembudidaya ikan hias tersebut. Dengan harga yang relatif terjangkau para penghobi berbondong-bondong ingin merawat ikan hias tersebut. Ikan cupang terdiri dari 73 spesies dan dibagi menjadi 13 kelompok, sedangkan di kalangan penggemar, ikan cupang umumnya terbagi atas tiga golongan yaitu cupang hias, cupang aduan, dan cupang liar [1]. Terdapat berbagai macam seni yang dikeluarkan oleh ikan hias ini seperti corak warna dan bentuk sirip. Saat ini, banyak kendala yang dirasakan baik dari kalangan pembudidaya maupun kalangan pengobi salah satunya adalah kurangnya pemahaman pengetahuan dan kesulitan untuk mendiagnosis gejala-gejala yang ditimbulkan pada ikan cupang tersebut. Kebanyakan pembudidaya dan penghobi ikan cupang hanya menduga-duga penyakit yang ada tanpa mengetahui gejala-gejala awal yang ditimbulkan. Dimana diagnosis merupakan sebagai usaha untuk mendeteksi, meneliti sebab - sebab, jenis - jenis, sifat - sifat dari kesulitan sesuai dengan 
fakta [2]. Dalam hal ini, mengatasi kendala tersebut, pembudidaya dan penghobi ikan cupang membutuhkan sistem basis pengetahuan untuk mengetahui informasi penyakit dengan mendiagnosis gejala-gejala yang ditimbulkan yaitu sistem pakar yang merupakan bagian lingkungan pengembangan dan lingkungan konsultasi [3].

\section{PENELITIAN RELEVAN}

Ada beberapa referensi yang diambil dari jurnal sebagai acuan dalam penelitian ini sebagai berikut :

Penelitian yang dilakukan oleh Arga Dian Setyo Wicaksono berjudul Sistem Pakar Penyakit Pada Ikan Lele Berbasis Web Menggunakan Metode Forward Chaining. Penelitian ini bertujuan untuk mengetahui kegagalan panen yang diakibatkan oleh penyakit dan virus. Hasil dari penelitian ini dengan adanya sistem pakar mampu untuk mendiagnosa dan memberikan informasi mengenai gejala dan penyakit pada ikan lele.

Penelitian selanjutnya dilakukan oleh Nurmala Mukhtar dan Samsudin berjudul Sistem Pakar Diagnosa Dampak Penggunaan Softlens Menggunakan Metode Backward Chaining. Penelitian ini menghasilkan sistem pakar yang mempermudah pengguna softlens untuk melakukan diagnosa berdasarkan gejala - gejala yang ditimbulkan dalam penggunaan softlens.

\section{METODE PENELITIAN}

Metode penelitian yang dilakukan yaitu dengan metode kualitatif adalah menggambarkan hasil penelitian yang dilakukan [4]. Dalam penelitian ini, penulis melakukan metode pengumpulan data untuk mendapatkan data-data serta informasi sebagai bahan pendukung dalam penyempurnaan hasil penelitian diantaranya :

\section{Studi Lapangan}

\section{a. Observasi}

Observasi salah satu kegiatan ilmiah empiris yang mendasarkan fakta-fakta lapangan maupun teks, melalui pengalaman panca indra tanpa menggunakan manipulasi apapun [5]. Peneliti mengamati secara langsung terhadap objek penelitian guna mendapatkan faktafakta permasalahan pada objek penelitian.

b. Wawancara

Wawancara metode pengumpulan data yang menhendaki komunikasi langsung antara penyelidik dengan subyek atau responden [6].

Peneliti melakukan wawancara untuk mencari data dan informasi terkait fakta-fakta permasalahan yang ada pada objek penelitian. Wawancara peneliti lakukan di lingkungan Gubuk Cupang Hias.

\section{Studi Pustaka}

Studi Pustaka berkaitan dengan kajian teoritis dan referensi lain yang ada kaitannya dengan nilai, budaya, norma yang berkembang pada situasi yang di teliti [7]. Metode kepustakaan dalam tahap pengumpulan data guna untuk mempelajari beberapa buku, jurnal, serta sarana lainnya seperti internet dan lain sebagainya. Peneliti membaca sejumlah buku dan jurnal-jurnal ilmiah guna untuk memecahkan sebuah permasalahan mengenai sistem pakar untuk diagnose jenis penyakit pada ikan cupang, metode forward chaining.

\section{HASIL DAN PEMBAHASAN}

Analisis Permasalahan

Setelah menganalisa sistem berjalan pada Gubuk Cupang Hias, maka peneliti memberikan kesimpulan bahwa selama ini dalam mendiagnosa atau mendeteksi penyakit masih menduga-duga tanpa mengetahui gejala-gejala yang ditimbulkan. Dalam hal ini, mendorong peneliti untuk mengembangkan aplikasi sistem pakar untuk mendiagnosa jenis penyakit pada ikan cupang berbasis Java pada Gubuk Cupang Hias. 
Adapun rincian dari penyelesaian masalah sebagai berikut :

1. Gubuk Cupang Hias harus memiliki aplikasi sistem pakar untuk mendiagnosa jenis penyakit pada ikan cupang.

2. Proses mendiagnosa jenis penyakit pada ikan cupang lebih efisien, efektif dan akurat.

3. Biaya yang mahal untuk berkonsultasi bagi pembudidaya dan penghobi ikan cupang.

4. Dalam proses mendeteksi penyakit yang ditimbulkan akibat gejala-gejala yang dirasakan oleh ikan cupang masih dalam keadaan menduga-duga.

\section{Use Case Diagram}

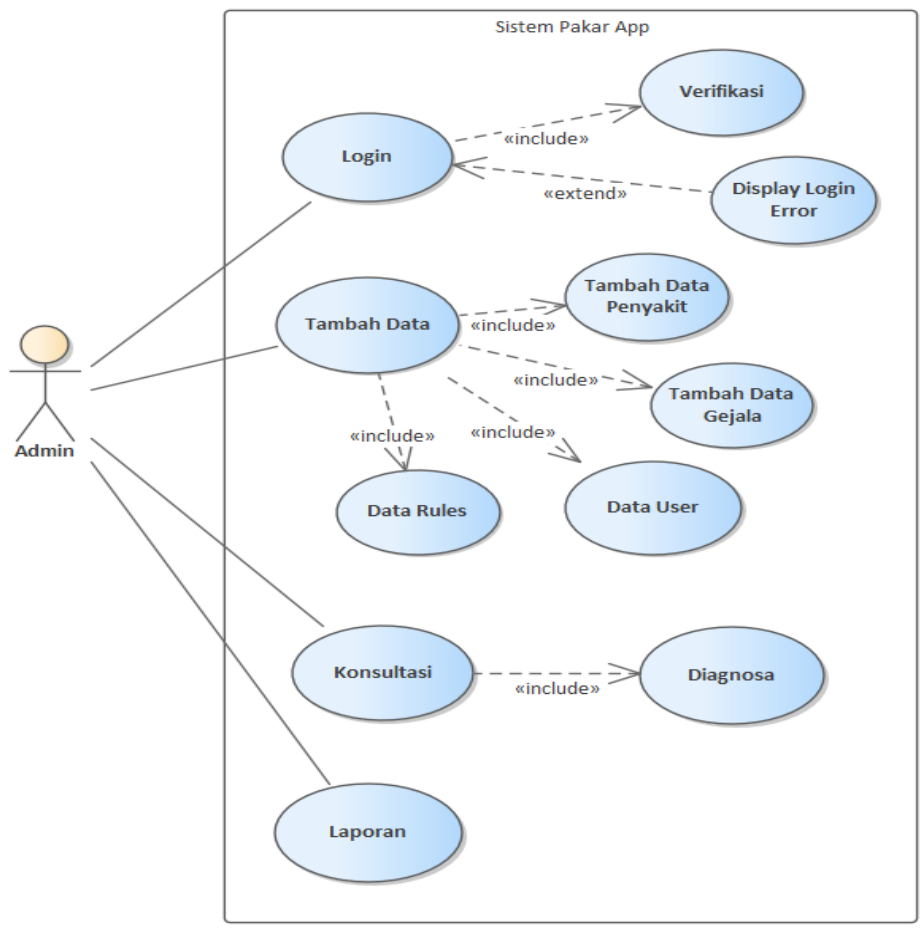

Gambar 1. Use Case Diagram

\section{Class Diagram}

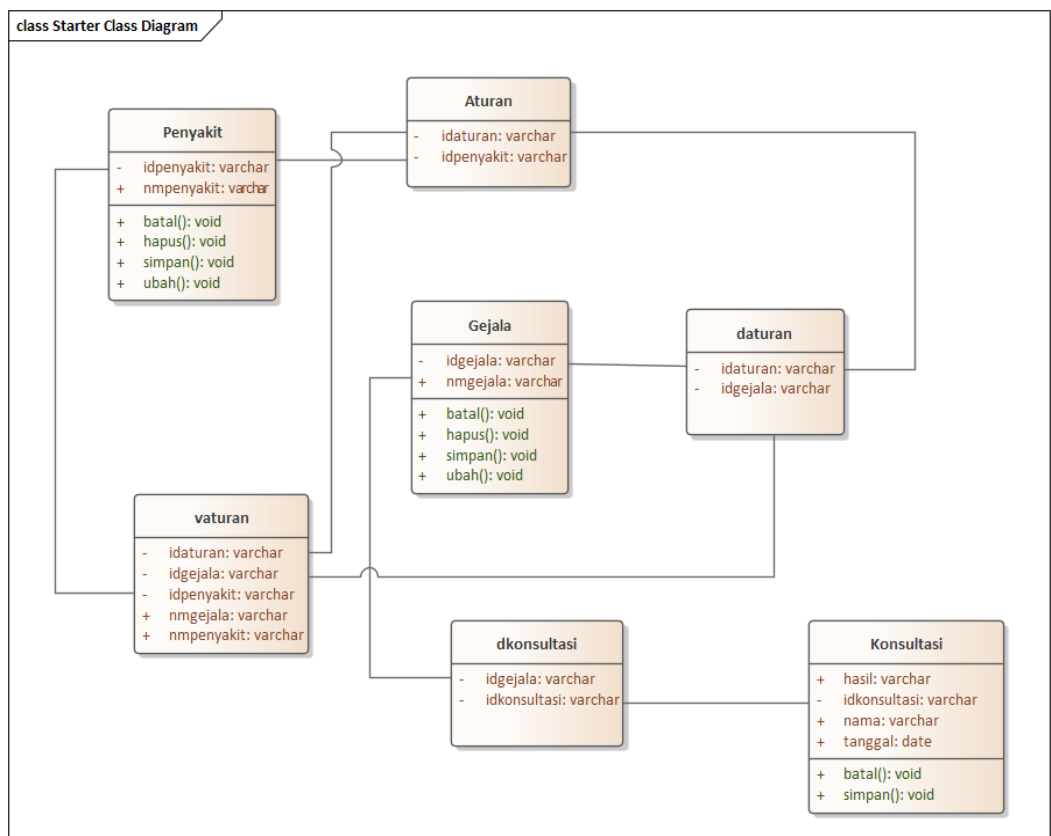

Gambar 2. Class Diagram 


\section{Tampilan Aplikasi}

Berikut ini tampilan aplikasi sistem pakar untuk mendiagnosa jenis penyakit pada ikan cupang

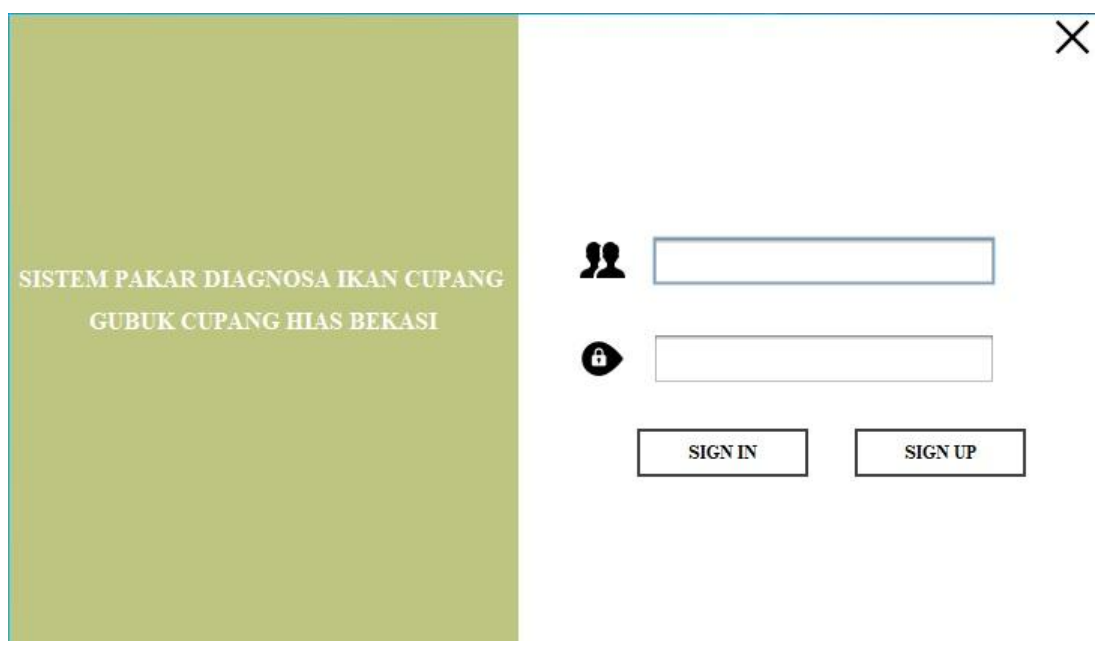

Gambar 3. Tampilan Halaman Login

Pada gambar 3 diatas menampilkan halaman login untuk akses masuk ke menu utama

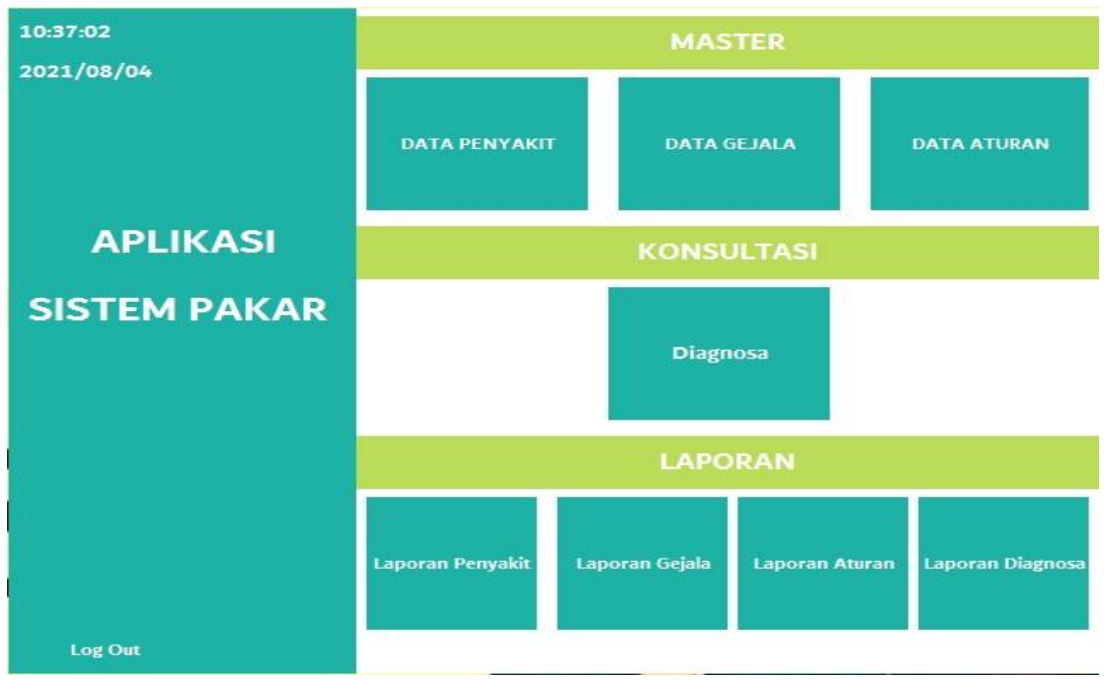

Gambar 4. Tampilan Menu Utama

Pada gambar 4 diatas menampilkan halaman menu-menu untuk melakukan proses selanjutnya. 


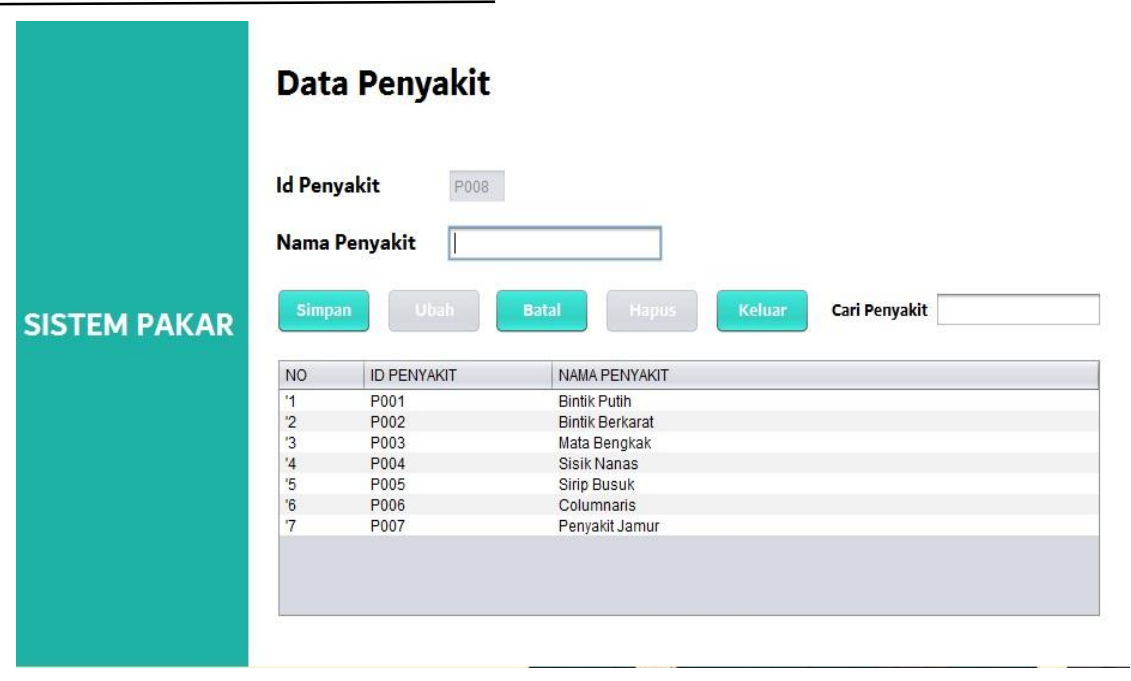

Gambar 5. Tampilan Data Penyakit

Pada form ini terdapat kolom-kolom untuk memasukan data penyakit dimana id penyakit sudah diotomatiskan dan hanya memasukkan nama penyakit.

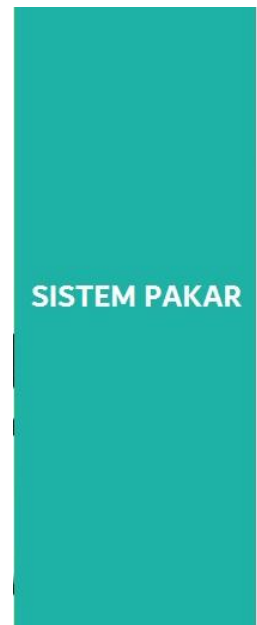

\section{Data Gejala}
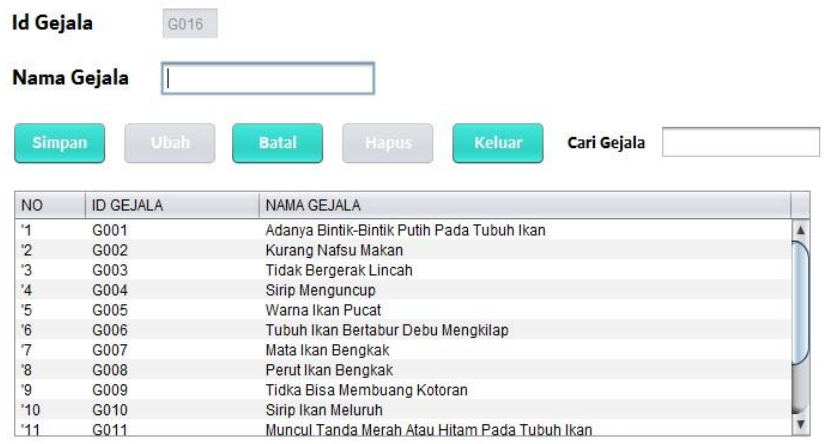

Gambar 6. Tampilan Data Gejala

Pada form ini terdapat kolom-kolom untuk memasukan data gejala dimana id gejala sudah diotomatiskan dan hanya memasukkan nama gejala.

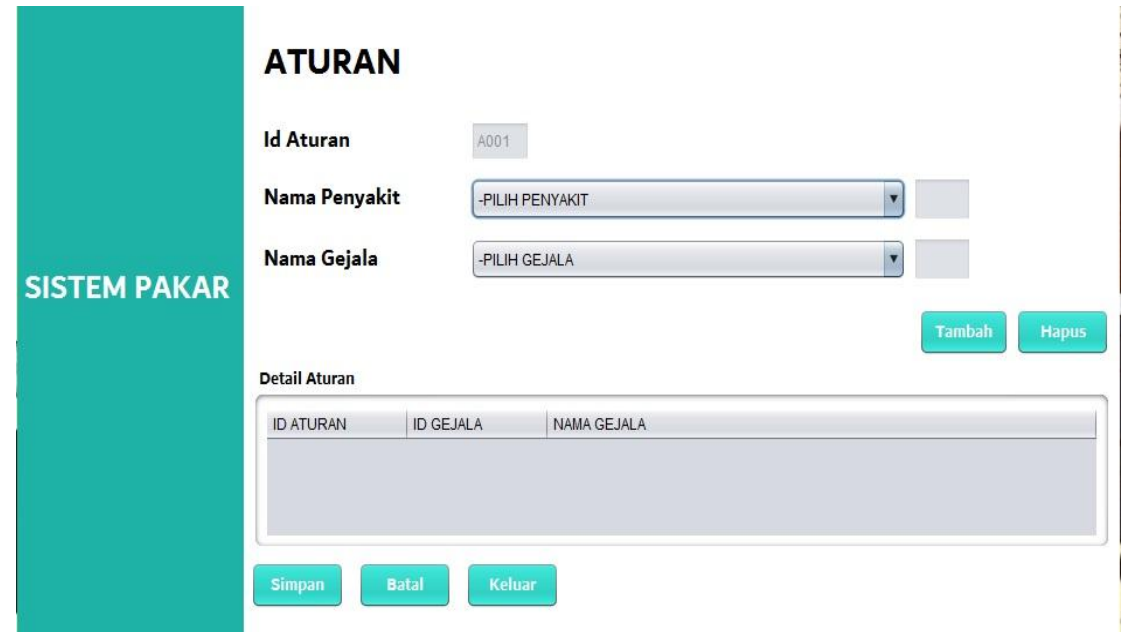

Gambar 7. Tampilan Data Aturan 
Pada form ini hanya memasukkan data penyakit dan data gejala sesuai dengan aturan pada jenis penyakit dan gejala yang ditimbulkan.

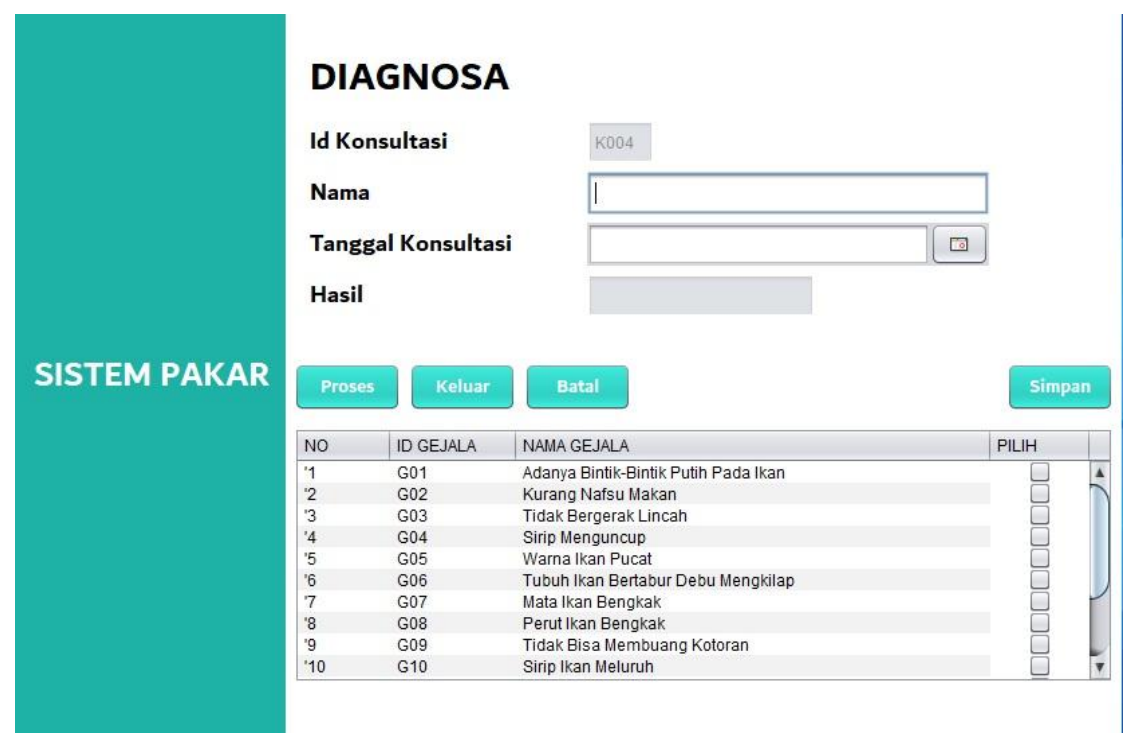

Gambar 8. Tampilan Diagnosa

Pada form ini merupakan halaman untuk diagnose jenis penyakit dengan memilih gejala-gejala yang sudah disediakan pada tabel.

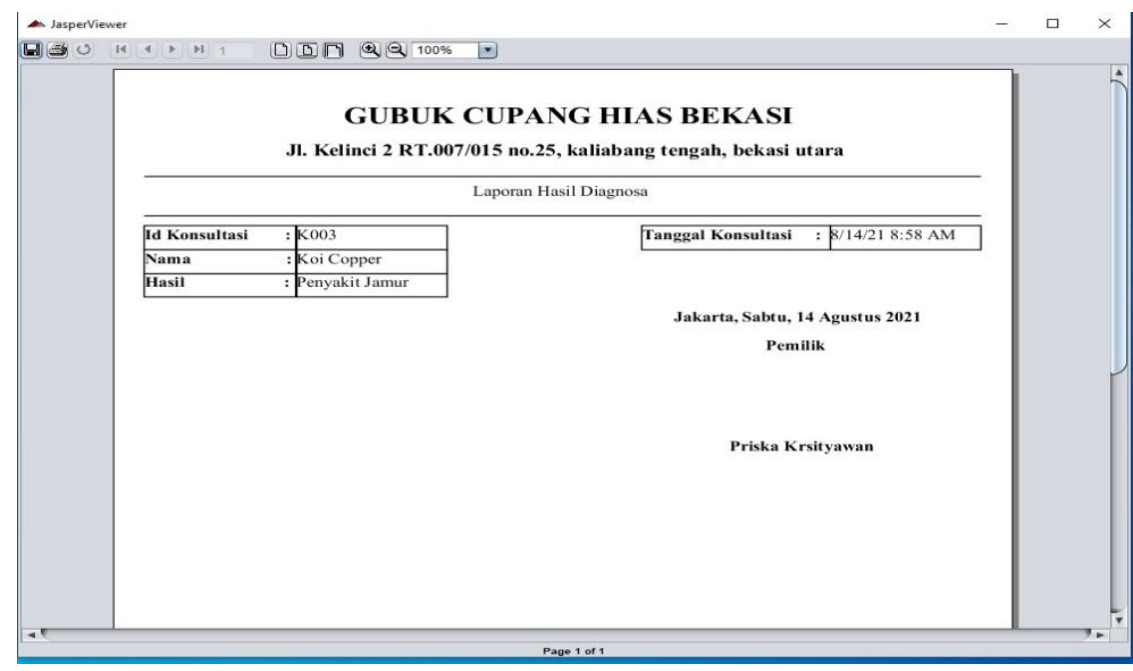

Gambar 9. Laporan Hasil Diagnosa

Pada gambar 9 merupakan tampilan output laporan hasil diagnosa yang siap dicetak.

\section{SIMPULAN}

Berdasarkan Analisa yang telah dilakukan peneliti, maka Aplikasi Sistem Pakar Untuk Diagnosa Jenis Penyakit Pada Ikan Cupang di Gubuk Cupang Hias dengan menggunakan metode Forward Chaining yang sudah dirancang peneliti dapat diterapkan di Gubuk Cupang Hias. Sehingga dapat disimpulkan bahwa dengan adanya sistem pakar ini memudahkan para pembudidaya dan penghobi ikan cupang tidak kesulitan lagi untuk mengetahui jenis penyakit pada ikan cupang melalui gejalagejala yang ditimbulkan serta dapat memeberikan jangkauan harga yang relatif tidak terlalu mahal untuk berkonsultasi. Dan dengan adanya sistem pakar ini menjadi lebh efektif dan efisien dalam mendiagnosa jenis penyakit pada ikan cupang serta memberikan informasi yang up to date terkait jenis penyakit lainnya 


\section{DAFTAR PUSTAKA}

[1] N. Neliana, "Mengenal 73 Spesiesnya Ikan Laga(Cupang) Lengkap," 2017. www.cianjurupdate.com/2017/03/ikan-cupang-dan-mengenal-73-spesiesnya.html.

[2] Mulyadi, Diagnosis Kesulitan Belajar dan Bimbingan Terhadap Kesulitan Belajar Khusus. Yogyakarta: Nuha Litera, 2010.

[3] Sutojo, E. Mulyanto, and V. Suhartono, Kecerdasan Buatan. Yogyakarta: Andi Offset, 2011.

[4] Sugiyono, Metode Penelitian Kualitatif, Kuantitatif dan R\&D. Bandung: PT Alfabet, 2016.

[5] H. Hasanah, "Teknik - Teknik Observasi," J. at-Taqaddum, vol. 8, 2016.

[6] Y. Riyanto, Metodologi Penelitian Pendidikan Kualitatif dan Kuantitatif. Surabaya: Unesa University Press, 2010.

[7] Sugiyono, Memahami Penelitian Kualitatif. Bandung: Alfabeta, 2012. 